\title{
Study of Variability and Genetic Parameters in Soybean Germplasm
}

\author{
Anil Kumar Bairwa*, P. S. Shukla, Kamendra Singh and Narendra Singh Dhaka
}

\author{
Department of Genetics and Plant Breeding, College of Agriculture, G B Pant University of \\ Agriculture and Technology, Pantnagar- 263145 (Uttarakhand), India
}

*Corresponding author

\section{A B S T R A C T}

The present study was carried out in at N E Borlaug Crop Research Center, G B Pant University of Agriculture and Technology Pantnagar, Uttarakhand to estimate the genetic parameters such as genotypic coefficient of variance (GCV), phenotypic coefficient of variance (PCV), heritability $\left(\mathrm{h}^{2}\right)$ and genetic advance as percent of mean (GAM)

Keywords

Genotypic, phenotypic, heritability, (GAM)

\section{Article Info}

\section{Accepted:}

05 February 2020

Available Online:

10 March 2020 and inter-character association for 12 quantitative traits of soybean (Glycine $\max \mathrm{L}$ ) germplasm. Experimental material of the investigation comprised of 276 genotypes along with 4 checks. During analysis of variance, characters days to $50 \%$ flowering, days to maturity, plant height, number of nodes per plant, number of pods per plant, 100 seed weight, dry matter weight per plant, plant population per plot and harvest index (\%) showed highly significant difference among check and significant difference showed for seed yield per plant. The PCV and GCV values ranged between $17.87 \%$ and $17.83 \%$ for plant population per plot and $4.75 \%$ and 2.62 for, days to $50 \%$ flowering and days to maturity, respectively. Highest heritability was observed for number of nodes per plant $(99.86 \%)$ and lowest heritability was observed for seed yield per plant $(62.20 \%)$. Genetic advance as percent of mean ranged from 36.66 (plant population per plot) to 4.62 (days to maturity). High heritability coupled with high genetic advance as percent of mean was observed for plant height, number of pods per plant, dry matter weight per plant, plant population per plot and harvest index \%. It can be concluded that these characters may be used as selection tool in future breeding programs.

\section{Introduction}

Soybean (Glycine max L.) is considered a miracle crop due to of its extraordinary qualities. Soybean is the one among the important vegetable food source in the world. It is grown in East and South East Asia mainly for food, feed and medicinal purposes (Lawrence, 2011). This plant contains about $37-42 \%$ of high quality protein, $6 \%$ ash, $29 \%$ carbohydrate and 17 to $24 \%$ oil, comprising $85 \%$ poly unsaturated fatty acids with two essential fatty acids (lenoleic \& linolenic acid) (Balasubramaniyan and Palaniappan, 2003).

Cultivated soybean is a diploid crop having chromosome number of $2 \mathrm{n}=40$. The estimates of world soybean area, production and productivity for 2018-19 are 127.19 million ha, 364.33 million tonnes and 2.854 
t/ha, respectively whereas, in India it is cultivated over an area of 10.80 million ha with production of 12.10 million tonnes and $1.120 \mathrm{t} / \mathrm{ha}$ (IISR, 2019).

India is leading soybean producing country in South Asia and $5^{\text {th }}$ largest producer after USA, Brazil, Argentina and China in the world. In India, major soybean producing states are Madhya Pradesh, Maharashtra, Karnataka, Rajasthan, Gujarat, Andhra Pradesh, Uttar Pradesh, Uttarakhand and Chhattisgarh. Low productivity in India is mainly due to the short growing period available in sub-tropical conditions, limited varietal stability and narrow genetic base of soybean cultivars (Singh and Hymowitz, 2001).

The estimation of genetic and phenotypic parameters like heritability, correlations and expected gains from selection have a prime role in genetic breeding programs. These parameters enable the breeders to make decisions about the appropriate methods to handle the populations and select the characteristics to be considered in initial and advanced steps of the breeding program (Farias, 2008).

The continuous improvement of genetic breeding of soybean depends on the information about genetic variability, genetic parameters and their application, that assists the breeders in reliable selection process. Important genetic parameters include heritability, and genetic advance that enable the plant breeders to select the best breeding strategy (Hamawaki, et al., 2012).

In this backdrop a research study was designed to estimate genotypic coefficient of variance (GCV), phenotypic coefficient of variance $(\mathrm{PCV})$, heritability $\left(\mathrm{h}^{2}\right)$, expected genetic advance (GA) and genetic advance as percent of mean (GAM) for yield and morphological traits of soybean that may be used as selection tools in future breeding programs.

Study of genetic variance is important in plant breeding in all the crops particularly in a crop like soybean, which is important oilseed crop in India. New genotypes play important role in generating variability as well as in the development of commercial varieties on the basis of desirable plant traits.

The extent of genetic variability available in a crop is pre-requisite for crop improvement due to the fact that efficiency of selection depends mainly on it. Heritability is a measure of transmissibility of characters from one generation to another generation.

The concept of heritability is important to determine whether the phenotypic differences observed among individuals are due to differences in their genetic make-up of individual or simply as a result of environmental factor (Comstock, et al., 1955).

Improvement in the mean genotypic value of selected plants over parental population is known as genetic advance. Thus study of Variability, heritability and genetic advance is the basic requirement to improve the crop and to develop varieties with desirable traits.

\section{Materials and Methods}

Experimental material of the investigation comprised of 276 genotypes along with 4 checks viz., JS 20-34, JS 95-60, NRC 86, and NRC 37. The experiment was conducted in augmented design with six blocks.

Each block planted with forty six genotypes and four checks. Each accession planted in a single row of $3 \mathrm{~m}$ length with row to row distance $45 \mathrm{~cm}$ and plant to plant distance 5-7 $\mathrm{cm}$. 


\section{Statistical analysis}

An augmented design which holds considerable promise for evaluation of large breeding material was used. The analysis of variance for augmented design was done using the method given by Federer (1956) as described by Federer and Ragavarao (1975) and Petersen (1985).The estimates of variability parameters are coefficient of variation at genotypic (GCV), phenotypic $(\mathrm{PCV})$ environmental level (ECV), heritability (\%) and genetic advance as percentage of mean.

In general the estimated values of PCV were higher than GCV for all the characters studied indicating role of environment on the performance of soybean genotypes. GCV and PCV values were categorized as low (0-10\%), moderate (10-20\%) and high (20 and above) as indicated by Sivasubramanian and Menon (1973).

The heritability was categorized as low (0$30 \%)$, moderate $(30-60 \%)$ and high (60 and above) as given by Robinson et al., (1949). Genetic advance as per cent mean was categorized as low (0-10\%), moderate (10$20 \%$ ) and high (20 and above) as given by Johnson et al., (1955).

\section{Results and Discussion}

Characters days to $50 \%$ flowering, days to maturity, plant height, number of nodes per plant, number of pods per plant, 100 seed weight, dry matter weight per plant, plant population per plot and harvest index (\%) showed highly significant difference among check and significant difference showed for seed yield per plant.

The significant difference indicates that these traits showed significant variation with the blocks. Highly significant differences among varieties were recorded for days to $50 \%$ flowering, days to maturity, plant height, number of pods per plant, dry matter weight per plant, plant population per plot and harvest index (\%).The number of primary branches per plant varies from 2.45 for CAT 294 to 3.9 for CAT 2337 B.

Only two accessions had significantly higher number of branches than best check CAT 307, CAT 2237 B (Table 1). Only one accession (EC 14476) was found to be significantly higher number of nodes per plant than best check. Forty six accessions were found to have significantly higher number of pods per plants against best check CAT 703, CAT 335, CAT 329, CAT 663, CAT 84.

Only three accessions were found to have significantly higher 100 seed weight over the best check EC 241656, DT 21, CAT 338. Only five accessions were found with significant high seed yield per plant over the best check CAT 833, CAT 286, CAT 284 B, CAT 2258, CAT 2239.

Highest genotypic coefficient of variance was observed for plant population per plot (17.83) number of pods per plant (15.46) followed by dry matter weight per plant (14.49). Moderate GCV was also estimated for plant height (13.56), harvest index \% (11.86) and 100seed weight (10.15).

Whereas low GCV was recorded for seed yield per plant $(\mathrm{g})$, number of primary branches per plant, number of nodes per plant, number of seeds per pod, days to $50 \%$ flowering and days to maturity as $8.91,6.87$, $6.73,6.48,4.72$ and 2.62 , respectively (Table 2). Rao, et al., (2014) found low GCV for number of seeds per pod. Moderate GCV was observed for dry matter weight per plant, number of pods per plant and plant height by Baraskar, et al., (2014) studied based on 61 genotypes of soybean. 
Phenotypic coefficient of variance (PCV) was estimated to be highest for plant population per plot (17.87), followed by number of pod per plant (15.49) and dry matter weight per plant (15.01). Moderate PCV was also observed for plant height, harvest index \%, 100- seed weight, seed yield per plant, and days to maturity as, 13.80, 12.57, 11.95, 11.30 and 11.28 , respectively.

Further low phenotypic coefficient of variance was noticed for number of primary branches per plant (7.09), number of seeds per pod (6.96), number of nodes per plant (6.73) and days to $50 \%$ flowering( 4.75). Moderate PCV was observed for 100 seed weight by Bangar, et al., (2003). Low PCV was observed for number of seed per pod by Rao, et al., (2014) and days to $50 \%$ flowering by observed by Aditya, et al., (2011).

The results indicated that phenotypic coefficient of variance (PCV \%) was slightly higher than that of genotypic coefficient of variance $(\mathrm{GCV} \%)$ for all the traits under studied. Narrow differences observed between PCV and GCV, which was observed for all of the traits under experiment thereby indicating environmental influence to be minimal and consequently greater role of factors on the expression of the traits.

Highest heritability was observed for number of nodes per plant (99.86) followed by number of pods per plant (99.70) and plant population per plot (99.60) recorded highest heritability values.

High heritability values were also recorded for days to $50 \%$ flowering (98.74), plant height (96.46), number of primary branches per plant (93.81), dry matter weight per plant (93.23), harvest index\% (89.01), number of seeds per pod (86.66), days to maturity (73.25), 100 seed weight (71.20), and lowest heritability was observed for seed yield per plant (62.20).
High heritability was observed for all the characters under study by Amrita, et al., (2014) and similar result found by Gohil, et al., (2016).

The estimates of genetic advance as per cent of mean were high for plant population per plot (36.66), number of pods per plant (31.80), dry matter weight per plant (28.82), plant height (27.43), and harvest index \% (23.04) indicating the preponderance of additive genetic effects in expression of these characters.

Therefore, phenotypic selection for these characters in segregating generations would likely to be more effective. Moderate genetic advance as percent of mean, was observed for 100 seed weight (17.76), seed yield per plant (14.48), number of nodes per plant (13.85) number of primary branches per plant (13.71) and number of seeds per pod (12.42). Low GA per cent of mean was observed for days to $50 \%$ flowering (9.66) and days to maturity (4.62).

High GA per cent of mean observed for number of pods per plant by Kumar et al., (2015); Aditya, et al., (2011). High heritability coupled with high genetic advance as percent of mean was observed for plant height, number of pods per plant, dry matter weight per plant, plant population per plot and harvest index $\%$.

High heritability coupled with moderate genetic advance as percent of mean was observed for number of primary branches per plant, number of nodes per plant, number of seeds per pod, 100 seed weight and seed yield per plant.

High heritability coupled with low genetic advance as percent of mean was observed for days to $50 \%$ flowering and days to maturity (Fig.1). 
Table.1 Analysis of variance (ANOVA) for yield and yield contributing traits of soybean genotypes

\begin{tabular}{|c|c|c|c|c|c|c|c|c|c|c|c|c|c|}
\hline \multirow{4}{*}{$\begin{array}{c}\text { Source } \\
\text { of } \\
\text { variation }\end{array}$} & \multirow{4}{*}{$\begin{array}{l}\text { Degree } \\
\text { of } \\
\text { freedom }\end{array}$} & \multicolumn{12}{|c|}{ MSS } \\
\hline & & \multicolumn{2}{|c|}{ Days to } & \multirow{2}{*}{$\begin{array}{c}\text { Plant } \\
\text { height } \\
\text { (cm) }\end{array}$} & \multirow{2}{*}{$\begin{array}{c}\text { Number } \\
\text { of } \\
\text { primary } \\
\text { branches } \\
\text { per plant }\end{array}$} & \multirow{2}{*}{$\begin{array}{l}\text { Number } \\
\text { of nodes } \\
\text { per plant }\end{array}$} & \multirow{2}{*}{$\begin{array}{c}\text { Number } \\
\text { of seed } \\
\text { per pod }\end{array}$} & \multirow{2}{*}{$\begin{array}{c}\text { Number of } \\
\text { pods per } \\
\text { plant }\end{array}$} & \multirow{2}{*}{$\begin{array}{c}\text { 100- } \\
\text { seed } \\
\text { weight } \\
(\mathrm{g})\end{array}$} & \multirow{2}{*}{$\begin{array}{l}\text { Seed } \\
\text { yield } \\
\text { per } \\
\text { plant } \\
(\mathrm{g})\end{array}$} & \multirow{2}{*}{$\begin{array}{c}\text { Dry } \\
\text { matter } \\
\text { weight } \\
\text { per plant } \\
\text { (g) }\end{array}$} & \multirow{2}{*}{$\begin{array}{c}\text { Plant } \\
\text { population } \\
\text { per plot }\end{array}$} & \multirow{2}{*}{$\begin{array}{c}\text { Harvest } \\
\text { index } \\
(\%)\end{array}$} \\
\hline & & $\begin{array}{c}50 \% \\
\text { flowering }\end{array}$ & maturity & & & & & & & & & & \\
\hline & & 1 & 2 & 3 & 4 & 5 & 6 & 7 & 8 & 9 & 10 & 11 & 12 \\
\hline Blocks & 5 & $41.799 * *$ & $39.507 * *$ & $406.518 * *$ & 0.166 & $3.151 *$ & 0.040 & $132.585 * *$ & 0.144 & $4.227^{*}$ & $53.892 * *$ & $347.277 * *$ & $38.606 * *$ \\
\hline Entries & 279 & $6.964 * *$ & $12.744 * *$ & $84.434 * *$ & 0.057 & 1.256 & 0.038 & $65.389 * *$ & 1.061 & 1.043 & $19.142 * *$ & $39.302 * *$ & $17.623 * *$ \\
\hline Checks & 3 & $113.013^{* *}$ & $173.069 * *$ & $325.176^{* *}$ & 0.377 & $18.595 * *$ & 0.958 & $408.760 * *$ & $6.104 * *$ & $4.478 *$ & $47.791 * *$ & $107.843^{* *}$ & $30.813 * *$ \\
\hline Varieties & 275 & $5.974 * *$ & $11.853 * *$ & $88.810 * *$ & 0.054 & 1.077 & 0.028 & $61.439 * *$ & 0.943 & 1.083 & $19.562 * *$ & $44.261 * *$ & $18.182 * *$ \\
\hline $\begin{array}{l}\text { Checks } \\
\text { vs. } \\
\text { variety }\end{array}$ & 1 & -38.825 & -223.331 & -1841.265 & -0.017 & -1.478 & 0.023 & 121.628 & 18.367 & -20.494 & -182.401 & -1529.951 & -175.799 \\
\hline Error & 15 & 0.070 & 3.017 & 2.945 & 0.003 & 0.001 & 0.003 & 0.173 & 0.250 & 0.392 & 1.244 & 0.164 & 1.883 \\
\hline Total & 299 & & & & & & & & & & & & \\
\hline \multicolumn{14}{|c|}{ LSD at $5 \%$} \\
\hline \multicolumn{2}{|c|}{ Between checks } & 0.341 & 2.234 & 2.207 & 0.072 & 0.047 & 0.077 & 0.535 & 0.643 & 0.806 & 1.434 & 0.521 & 1.765 \\
\hline \multicolumn{2}{|c|}{ Between genotype } & 0.836 & 5.473 & 5.407 & 0.176 & 0.116 & 0.188 & 1.312 & 1.176 & 1.174 & 3.514 & 1.277 & 4.324 \\
\hline \multicolumn{2}{|c|}{$\begin{array}{l}\text { Between entries of } \\
\text { same block }\end{array}$} & 0.934 & 6.119 & 6.045 & 0.197 & 0.130 & 0.210 & 1.467 & 1.762 & 2.207 & 3.929 & 1.428 & 4.834 \\
\hline \multicolumn{2}{|c|}{$\begin{array}{l}\text { Between check vs. } \\
\text { genotypes }\end{array}$} & 0.713 & 4.673 & 4.617 & 0.150 & 0.099 & 0.161 & 1.120 & 1.346 & 1.686 & 3.001 & 1.090 & 3.692 \\
\hline
\end{tabular}

* Significant at 5\% level of probability, ** Significant at $1 \%$ level of probability 
Table.2 Co-efficient of variance, heritability, and genetic advance as per cent of mean for yield and yield contributing in soybean germplasm

\begin{tabular}{|c|c|c|c|c|c|c|c|}
\hline S. No. & Name of characters & GCV\% & ECV\% & PCV\% & $h^{2}(b)$ in $\%$ & GA & GA as \% of mean \\
\hline 1 & Days to $50 \%$ flowering & 4.72 & 0.53 & 4.75 & 98.74 & 4.81 & 9.66 \\
\hline 2 & Days to maturity & 2.62 & 1.58 & 11.28 & 73.25 & 5.07 & 4.62 \\
\hline 3 & Plant height $(\mathrm{cm})$ & 13.56 & 2.60 & 13.80 & 96.46 & 18.13 & 27.43 \\
\hline 4 & Number of primary branches per plant & 6.87 & 1.76 & 7.09 & 93.81 & 0.44 & 13.71 \\
\hline 5 & Number of nodes per plant & 6.73 & 0.25 & 6.73 & 99.86 & 2.07 & 13.85 \\
\hline 6 & Number of seeds per pod & 6.48 & 2.54 & 6.96 & 86.66 & 0.29 & 12.42 \\
\hline 7 & Number of pods per plant & 15.46 & 0.85 & 15.49 & 99.70 & 15.57 & 31.80 \\
\hline 8 & 100 Seed weight $(g)$ & 10.15 & 6.30 & 11.95 & 72.16 & 1.41 & 17.76 \\
\hline 9 & Seed yield per plant (g) & 8.91 & 6.95 & 11.30 & 62.20 & 1.31 & 14.48 \\
\hline 10 & Dry matter weight per plant (g) & 14.49 & 3.90 & 15.01 & 93.23 & 8.23 & 28.82 \\
\hline 11 & Plant population per plot & 17.83 & 1.13 & 17.87 & 99.60 & 13.20 & 36.66 \\
\hline 12 & Harvest index $(\%)$ & 11.86 & 4.17 & 12.57 & 89.01 & 7.59 & 23.04 \\
\hline
\end{tabular}




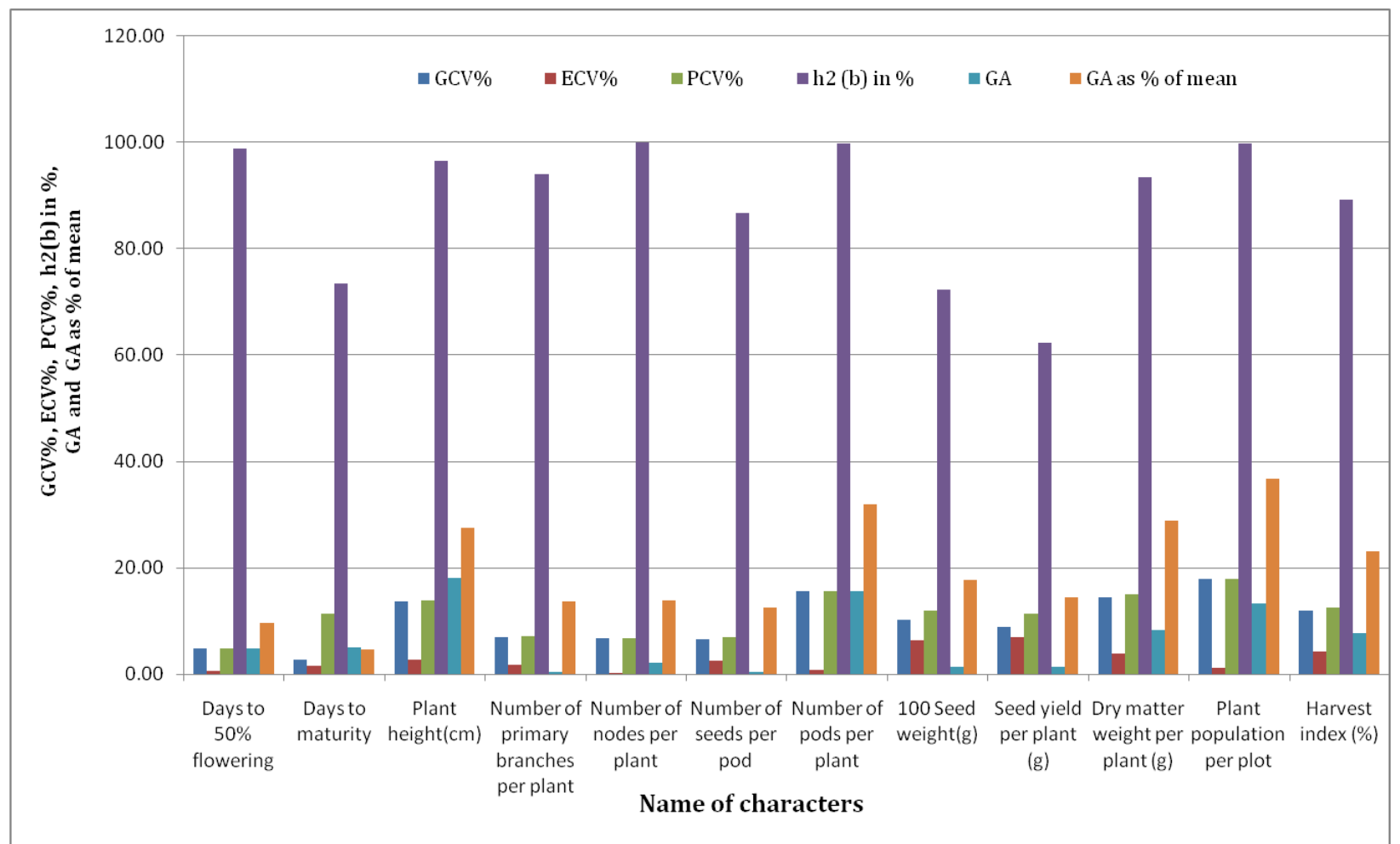

Fig.1 Graphical presentation of GCV, ECV, PCV, ${ }^{2}(\mathrm{~b})$ in $\%, \mathrm{GA} \%$ and $\mathrm{GA}$ as $\%$ of mean for yield and yield contributing traits of soybean genotypes

In conclusion, high heritability along with high genetic advance also indicated the occurrence of additive type of gene action which provides ample scope for improvement in these traits through simple selection. In case of days to $50 \%$ flowering where high heritability was coupled with moderate genetic advance as percent of mean indicating that gene governing this character is under the influence of dominant effect so one can go for the progeny test or heterosis breeding for the improvement of this character.

For harvest index both heritability and genetic advance had high value that indicates less influence of environmental factor that means phenotypic selection is effective for this character.

\section{References}

Aditya, J. P., Bhartiya, P. and Bhartiya, A. 2011. Genetic variability, heritability and

character association for yield and component characters in soybean [Glycine $\max$

(L.) Merrill]. Journal of Central European Agriculture. 12(1): 27-34.

Amrita, B., Shrivastava, A. N., Bisen, R. and Mishra, S. 2014. Genetic variability, association and path analyses in advanced generation fixed lines of soybean

[Glycine max (L.) Merrill]. Soybean Research. 12(1): 20-27.

Anonymous, 2019. Directors Report and summery Tables of Experiment. Indian institute of Soybean Research.1-13.

Baraskar, V. V., Kachhadia, V. H., VachhanI, J. H., Barad, H. R., Patel, M. B. and Darwankar, M. S. 2014.Genetic variability, heritability and genetic advance in soybean [Glycine $\max$ (L.) Merrill]. Electronic Journal of Plant Breeding. 
5(4):802-806.

Federer, W. T., Nair, R. C., and Raghavarao, D. 1975. Some augmented row-column designs. Biometrics. 31:361-374.

Federer, W.T. 1956. Augmented. (or Hoonuiaku) design. Hawai.Plant Rec. 55:191-208.

Gohil, V. N., Pandya, H. M. and Mehta, D. R. 2016. Genetic variability for seed yield and its component traits in soybean. Agricultural Science Digest. 26(1): 7374.

Hymowitz, T. 1970. On the domestication of the soybean. Econ. Bot. 24:408-421.

Johnson, H. W., Robinson, H. F. and Comstock, R. E. 1955. Estimates of genetic and environmental variability in soybean. Agron. J. 47: 314-318.

Kumar, A., Lal, G. M. and Mishra, P. K. 2015. Genetic variability and character association for yield and its components in soybean.Annals of Plant and Soil
Research. 16(1): 48-52.

Lush, J. L. 1949. Heritability of quantitative characters of farm animals.Proc. $8^{\text {th }}$ Int. Cong. of Genet. Hereditis. 356-375.

Peterson, R.G. 1985. Augmented design for preliminary yield trial (revised). Rachis. 4:27-32.

Rao, S. S., Singh, V. J., Srihima, G. and Rangare, N. R. 2014. Assessment of genetic variability of the main yield related characters in soybean. International

Journal of Food, Agriculture and Veterinary Sciences. 4(2): 69-74

Robinson, H. F., Comstock, R. E. and Harvey, P. H. (1949). Estimation of heritability and the degree of dominance in corn. Agron. J. 41: 353-359.

Sivasubramanian, S. and Menon, P. M. 1973.Genotypic and phenotypic variability in rice.Madras Agric. J. 60 (9-13): 1093-1096.

\section{How to cite this article:}

Anil Kumar Bairwa,P. S. Shukla, Kamendra Singh and Narendra Singh Dhaka. 2020. Study of Variability and Genetic Parameters in Soybean Germplasm. Int.J.Curr.Microbiol.App.Sci. 9(03): 978-985. doi: https://doi.org/10.20546/ijcmas.2020.903.115 